\title{
PENGEMBANGAN MODUL PEMBELAJARAN KIMIA BERBASIS MODEL PERUBAHAN KONSEPTUAL ED3U (EXPLORE, DIAGNOSE, DESIGN, DISCUSS, USE) TERINTEGRASI MULTI REPRESENTASI PADA MATERI STRUKTUR ATOM
}

\author{
Zonalia Fitriza ${ }^{1)}$ Fauzana Gazali ${ }^{2)}$ \\ ${ }^{1)}$ Jurusan Kimia FMIPA Universitas Negeri Padang \\ 2) Jurusan Kimia FMIPA Universitas Negeri Padang \\ zonaliafitriza@gmail.com
}

\begin{abstract}
This research aims to produce a valid chemistry module based conceptual change model Explore, Diagnose, Design, Discuss and Use (ED3U). The steps of this model are align with scientific approach which is an approach used in current curriculum. This model make the student find their own conception and considering their prior conception will resist or they need alternative conception so that they can have scientific conception. In order to optimalize this, the module is presented using three level chemistry representations that are macroscopic, submicroscopic and symbolic. Developments of this module used 4-D model (define, design, develop, disseminate) with check list as a non test instrument for observation in define step. Beside, it also use questioner to determine whether the module is valid or not. The data was analyzed by Kappa Cohen Formula. Based on the three validators who are the chemistry education lecturers and two validators who are lecturers of Design Communication Visual found that the value of $k$ is 0,829 for content validation and 0,69 for graphics validation. It means the module is valid in high category.
\end{abstract}

Keywords : Atomic structure, ED3U model, Module, Multiple representation

\section{PENDAHULUAN}

Kurikulum 2013 merupakan kurikulum yang dikembangkan dengan penyempurnaan berbagai pola, antara lain penguatan pola pembelajaran berpusat pada peserta didik, pola pembelajaran interaktif (guru-siswa-masyarakatalam-sumber belajar) dan pembelajaran aktif mencari dengan pendekatan saintifik (Salinan Lampiran I Peraturan Menteri Pendidikan Kebudayaan RI Nomor 59 tahun 2014). Selain itu, sasaran pembelajaran kurikulum 2013 mencakup pengembangan ranah sikap, pe ngetahuan dan keterampilan (Salinan Lampiran Peraturan Menteri Pendidikan dan Kebudayaan RI Nomor 65 tahun 2013). Pengembangan polapola tersebut diharapkan dapat meningkatkan kualitas pendidikan Indonesia, oleh sebab itu berbagai tingkat satuan pendidikan termasuk sekolah menengah atas telah menerapkan kurikulum ini mulai tahun ajaran 2013/2014.

Penerapan kurikulum 2013 juga dilaksana kan pada pembelajaran kimia yang menerapkan lima pengalaman belajar pokok yaitu me ngamati, menanya, mengumpulkan informasi, mengasosiasi dan mengkomunikasikan (Salinan Lampiran I Peraturan Menteri Pendidikan Kebudayaan RI Nomor 81A tahun 2013). Lima kegiatan ini diharapkan terintegrasi dalam model dan strategi pembelajaran yang diterapkan oleh guru sehingga siswa menjadi lebih aktif dan terlatih untuk menemukan konsep sendiri dengan instruksi- instruksi dari guru. Namun, permasalahan yang dihadapi adalah pelaksanaan pembelajaran dengan mengintegrasikan kelima kegiatan tersebut memerlukan waktu yang lebih lama dibandingkan pembelajaran klasikal karena pembelajaran dengan pendekatan saintifik ber pusat pada siswa, sedangkan siswa memiliki ke mampuan yang berbeda-beda sehingga kecepatannya dalam menyelesaikan tujuan pem belajaran berbeda pula. Oleh sebab itu selain pembelajaran di sekolah, siswa juga memerlu kan bahan ajar yang membantu mereka untuk memahami konsep-konsep untuk mencapai tujuan pembelajaran sesuai kecepatan mereka masing-masing. Bahan ajar yang dimaksud adalah berupa modul karena modul berisi elemen-elemen bahan ajar paling lengkap di bandingkan yang lainnya (Depdiknas,2008)

Modul yang digunakan haruslah berbasis sebuah model yang tahapannya mengintegrasi kan kegiatan mengamati, menanya, mengumpul kan informasi, mengasosiasikan dan meng komunikasikan. Salah satu model yang melibat 
kan kegiatan- kegiatan tersebut adalah Model Perubahan Konseptual ED3U (Explore, Diag nose, Design, Discuss and Use). Fase ekplorasi (explore) adalah fase untuk mengaktifkan ke ingintahuan siswa dengan mengekplore fenomena terkait konsep tertentu. Fase diagnose (diagnose) adalah fasa dimana siswa mem persepsikan konsepsinya dengan melihat konsep si alternatif sebagai sesuatu yang masuk akal. Fase berikutnya adalah fase diskusi (discuss) dimana siswa akan mempertimbangkan konsepsi alternatif untuk memutuskan apakah konsep tersebut akan menggantikan konsep awal atau tidak. Fase terakhir adalah penggunaan (use) yaitu pengaplikasian konsepsi baru mereka pada fenomena yang relevan.. Model tersebut di kembangkan oleh Richard R. Shope dan William F. McComas dengan tujuan memediasi perubahan konseptual dan transformasi pe laksanaan pembelajaran terpusat pada siswa dengan memfasilitasi siswa untuk berfikir secara saintifik (Shope, 2015).

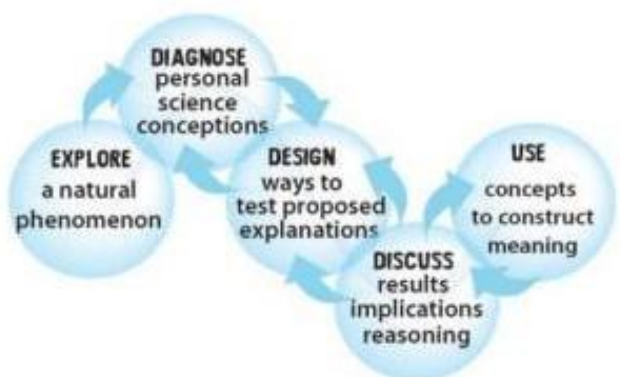

Gambar 1. Model Instruksional ED3U

Perubahan konseptual merupakan salah satu hal yang harus menjadi perhatian dalam pembelajaran karena siswa membawa konsep awal atau pre-konsep sebelum memulai pembelajaran. Konsep awal tersebut bisa merupakan konsep dasar yang benar, bisa jadi konsep dasar yang salah atau miskonsepsi. Konsep tersebut akan berubah menjadi konsep ilmiah jika melewati proses pembelajaran yang benar. Unsur penting dalam proses pembelajaran untuk sampai pada konsepsi ilmiah adalah kompleksitas yang berupa penambahan ilmu pengetahuan terkait konsepsi awal dan inklusivitas yang berkaitan dengan aspek-aspek baru dan berbeda dengan konsepsi awal selama pembelajaran (Park, 2009).

Kompleksitas dan inklusifitas tersebut bisa ditemui siswa melalui inkuiri dari informasi yang diperoleh dari sumber belajar, fenomena alam, dan pengalaman belajar lainnya.
Informasi-informasi dan pengalaman belajar tersebut bisa diinterpretasikan secara benar sehingga siswa akhirnya memiliki konsep target/ ilmiah, namun bisa juga diinterpretasikan secara tidak tepat atau tidak lengkap sehingga terjadi miskonepsi (Kutluy, 2005)

Konsep-konsep dalam pembelajaran kimia pada umumnya adalah konsep yang abstrak yang bisa dijelaskan dengan tiga representasi kimia yang disebut multi representasi yaitu level makro, sub-mikro dan simbolik. Metode pembelajaran kimia dengan mengintegrasikan ketiga representasi tersebut akan meningkatkan kemampuan penalaran siswa (Sunyono, 2015). Khususnya untuk konsepkonsep struktur atom yang merupakan konsep dasar dalam memahami berbagai konsep kimia lainnya, beberapa konsep dalam struktur atom yang cenderung tidak dapat dipresentasikan siswa dengan baik antara lain konsep atom dalton, thompson dan rutherford, model atom rutherford, bohr dan mekanika gelombang serta konfigurasi elektron suatu ion (Fitriza, 2015). Konsep-konsep abstrak tersebut akan lebih baik dipelajari melalui multi representasi yang diintegrasikan pada model ED3U. Multipel representasi akan melengkapi kegiatan pada fase diskusi, dimana siswa akanmempertimbangkan apakah konsepsi awal mereka harus dipertahan kan atau mengalami perubahan menjadi konsepsi baru.

\section{METODE PENELITIAN}

Prosedur penelitian yang dilakukan pada penelitian ini dengan menggunakan model pengembangan yaitu model 4-D (four D models) seperti yang dikembangkan oleh Thiagarajan, Semmel dan Semmel. Model 4-D ini terdiri dari 4 tahap utama, yaitu: (1) define (pendefinisian), (2) design (perancangan), (3) develop (pengembangan) dan (4) disseminate (penyebaran) (Trianto, 2010).

1. Tahap Pendefinisian(Define)

Pelaksanaan penelitian dimulai dari tahap define. Langkah-langkah yang dilakukan pada tahap ini meliputi 4 langkah, yaitu:

a. Analisis Ujung Depan

Pada tahap ini dilakukan analisis kurikulum dengan melihat proses pembelajaran yang terjadi di lapangan dan membandingkan dengan tuntutan kurikulum 2013 yaitu kemampu an komunikasi, berpikir kritis dan proses yang berpusat pada siswa. Hal ini dilakukan dengan 
observasi dibeberapa SMA Sumatera Barat. Berdasarkan hal ini, selanjutnya disusun bahan ajar pembelajaran kimia yang relevan.

b. Analisis Siswa

Analisis siswa bertujuan untuk melihat karakteristik siswa yang dijadikan subjek uji coba modul pembelajaran kimia Berbasis Model Perubahan Konseptual ED3U (Explore, Diag nose, Design, Discuss, Use) Terintegrasi Multi Representasi Pada Materi Struktur Atom yang dihasilkan. Pada penelitian karakteristik siswa yang diamati yaitu dari segi usia/ kelas dan pengalaman belajar.

c. Analisis Tugas

Pada analisis tugas dilakukan analisis terhadap KI dan KD yang akan dikembangkan bahan ajar pembelajarannya. Dalam penelitian ini yang akan dianalisis adalah KI dan KD pada materi struktur atom yang dipelajari di kelas $\mathrm{X}$ SMA yang terdapat pada silabus kurikulum 2013 sehingga didapatkan indikator dan tujuan pembelajaran yang akan dicapai.

d. Analisis Konsep

Analisis konsep dilakukan untuk meng identifikasi konsep-konsep utama yang akan diajarkan dan menyusunnya secara sistematis serta mengkaitkan satu konsep dengan konsep lain yang relevan. Pada penelitian dilakukan dengan mengidentifikasi dan menyusun konsepkonsep materi struktur atom dengan cara yang mudah dipahami siswa.

\section{Tahap Perancangan(Design)}

Tahap ini dilaksanakan dengan merancang modul pembelajaran kimia Berbasis Model Perubahan Konseptual ED3U (Explore, Diag nose, Design, Discuss, Use) Terintegrasi Multi Representasi Pada Materi Struktur Atom. Langkah-langkah yang dilakukan pada tahap ini adalah:

a. Pemilihan Format

Tahap ini dilakukan dengan pemilihan format modul yang sesuai dengan analisis pada tahap pendefinisian (Define). Modul Berbasis Model Perubahan Konseptual ED3U (Explore, Diagnose, Design, Discuss, Use) dipilih dan mengintegrasikan Multi Representasi ke dalamnya

b. Perancangan Modul

Pada tahap ini dirancang Modul pem belajaran kimia sesuai dengan format penulisan dalam buku Panduan Pengembangan Bahan Ajar dari depdiknas tahun 2008. Berdasarkan hal ini akan dihasilkan modul pembelajaran kimia yang akan dikembangkan.

3. Tahap Pengembangan (Develop)

Pada tahap pengembangan dilakukan modifikasi produk yang dihasilkan pada tahap perancangan, sebelum menjadi produk akhir yang siap untuk digunakan. Dalam tahap ini dilakukan Uji validitas, revisi dan uji praktikalitas produk yang dihasilkan.

a. Uji validitas

Uji validitas bertujuan untuk melihat kategori validitas mengenai isi, kebahasaan, penyajian, dan kegrafisan dari modul yang dikembangkan. Validasi dilakukan oleh dosen dan guru sebagai validator. Kritikan, masukan, dan saran dari para validator dijadikan dasar untuk merevisi Modul Berbasis Model Perubahan Konseptual ED3U (Explore, Diagnose, Design, Discuss, Use)

Instrumen validitas Modul Berbasis Model Perubahan Konseptual ED3U (Explore, Diagnose, Design, Discuss, Use) yang diguna kan berupa angket untuk menilai validitas isi, konstruk, kebahasaan dan kegrafisan dari modul yang dihasilkan. Pada bagian akhir angket diberikan kesempatan bagi validator untuk memberikan saran dan memutuskan hasil dari penilaian yang telah diberikan. Data yang didapatkan digunakan untuk mengungkapkan kategori validitas Modul Berbasis Model Perubahan Konseptual ED3U (Explore, Diag nose, Design, Discuss, Use) yang disusun.

Validator diberikan angket yang berisi pernyataan-pernyataan untuk kemudian memberi kan penilaian terhadap masing-masing pernyata an tersebut. Penilaian validator terhadap masingmasing pernyataan dianalisis dengan mengguna kan formula Kappa Cohen yang telah di modifikasi, dimana pada akhir pengolahan diperoleh momenkappa.

b. Revisi

Tahap revisi ini bertujuan untuk memperbaiki bagian Modul Berbasis Model Perubahan Konseptual ED3U (Explore, Diagnose, Design, Discuss, Use) yang dianggap masih kurang tepat oleh validator sebelum produk diuji coba. Modul pembelajaran kimia yang sudah diperbaiki kemudian diberikan kembali kepada validator untuk didiskusikan lebih lanjut sebelum diuji coba. Revisi dihentikan apabila validator sudah menyatakan Modul Berbasis Model Perubahan Konseptual ED3U (Explore, Diagnose, Design, Discuss, Use) yang dihasilkan sudah dapat diujicobakan. 
Instrumen yang digunakan adalah lembar an observasi untuk pelaksanaan penelitian pada tahap pendefenisian. Teknik non tes lain yang digunakan adalah pemberian angket. Angket adalah sebuah daftar pertanyaan yang harus diisi oleh orang yang akan dievaluasi (responden) ( $\mathrm{Dj}, 2010)$. Instrumen yang digunakan adalah lembaran angket untuk pelaksanaan penelitian pada tahapan pengembangan. Lembaran angket digunakan untuk uji validitas yang kemudian diinterpretasikan dengan menggunakan formula kappa Cohen (Boslaugh, 2008)

Formula tersebut adalah sebagai berikut.

moment kappa $(\mathrm{k})=\frac{P o-P e}{1-P e}$

$P o$ adalah proporsi yang terealisasi, dihitung dengan cara: $P e$ adalah proporsi yang tidak terealisasi, dihitung dengan cara:

$$
P o=\frac{\text { Jumlah nilai yang diberi validator }}{\text { Jumlah nilai maksimal }}
$$

$\mathrm{Pe}=\frac{\text { jwmiah nilai maksimal-jumlah nilai yang diberi validator }}{\text { jwmiah nilai maksimal }}$

Momen Kappa (k) berkisar dari 0 sampai 1, dengan interpretasi menurut Boslaugh \& Watters (2008) disajikan pada Tabel 1.

Tabel 1. Interpretasi Nilai Momen Kappa (k) Menurut Boslaugh \&Watters

\begin{tabular}{|c|c|}
\hline Nilai $\mathbf{k}$ & Kategori \\
\hline $\mathbf{0 , 8 1}-\mathbf{1 , 0 0}$ & Sangat Tinggi \\
\hline $\mathbf{0 , 6 1}-\mathbf{0 , 8 0}$ & Tinggi \\
\hline $\mathbf{0 , 4 1}-\mathbf{0 , 6 0}$ & Sedang \\
\hline $\mathbf{0 , 2 1}-\mathbf{0 , 4 0}$ & Rendah \\
\hline $\mathbf{0 , 0 0}-\mathbf{0 , 2 0}$ & Sangat Rendah \\
\hline$<\mathbf{0 , 0 0}$ & Tidakdiperhitungkan \\
\hline
\end{tabular}

\section{HASIL DAN PEMBAHASAN}

Penelitian yang dilakukan adalah peneliti an pengembangan, yaitu pengembangan Modul Pembelajaran kimia berbasis model perubahan konseptual ED3U (explore, diagnose, design, Discuss, use) terintegrasi multi representasi pada materi struktur atom. Pengembangan modul ini menggunakan model 4D yaitu define, design, develope, dessiminate. Namun, penelitian ini dibatasi sampai pada tahapan ketiga. Tahapantahapan tersebut adalah sebagai berikut:

1. Tahapan pertama pada pengembangan modul ini adalah mendefinisikan (define) yang dilakukan dalam beberapa tahapan yaitu:

a. Analisis UjungDepan

Tahapan ini bertujuan untuk mengetahui proses pembelajaran yang terjadi di sekolah dan membandingkannya dengan tuntutan kurikulum. Tahapan ini dilakukan dengan observasi pada beberapa sekolah yaitu SMA N 12 Padang, SMA N 5 Padang, SMA Pembangunan Padang dan MAN 3 Padang. Pemilihan Sekolah menengah di kota Padang ini adalah sebagai representasi sekolah menengah negeri, swasta dan madrasah. Hasil dari observasi tersebut menunjukkan bahwa $73 \%$ guru jarang dan tidak pernah menggunakan media pembelajaran, $64 \%$ guru jarang menyediakan bahan ajar dan $73 \%$ guru jarang dan tidak pernah menggunakan multiple representasi baik dalam pembelajaran ataupun dalam bahan ajar yang digunakan.

b. Analisis Siswa

Analisis siswa bertujuan untuk menge tahui konsep-konsep yang tidak dipahami siswa dan konsep-konsep yang siswa cenderung miskonsepsi. Analisis ini dilakukan dengan memberikan tes diagnostik yaitu dengan tujuh open ended questions.

Tujuh soal ini diberikan pada 135 siswa yang berasal dari enam SMA Negri dan Swasta di kota Padang yaitu SMA Pembangunan Labor UNP, SMA N 12 Padang, SMA N 5 Padang, SMA N 3 Padang, SMA N 4 Padang, SMA N 7 Padang. Hasil Tes dikelompokkan berdasarkan level jawaban siswa.

Analisis terhadap konsepsi siswa me ngenai konfigurasi elektron atom menunjukkan bahwa siswa lebih memahami konfigurasi elektron berdasarkan tingkat energi kulit atom berdasarkan teori atom Bohr dibandingkan konfigurasi elektron berdasarkan tingkat energi orbital berdasarkan teori mekanika gelombang. Selain itu, sebagian besar siswa tidak memahami konfigurasi elektron ion dan hanya $20 \%$ siswa yang bisa menuliskan konfigurasi elektron ion berdasarkan teori mekanika gelombang. Konsep lain yang tidak dipahami sebagian besar siswa adalah perioda dan golongan. Konsep yang benar hanya dimiliki oleh $21 \%$ siswa berdasar kan teori atom mekanika gelombang, $18 \%$ ber dasarkan teori atom bohr sedangkan 53\% siswa tidak memiliki konsep yang benar. Sedangkan untuk konsep partikel penyusun atom sudah dipahami dengan baik oleh siswa.

Selain itu siswa juga mengalami beberapa miskonsepsi. Siswa mengalami miskonsepsi dalam menggambarkan model atom Rutherford, 
Bohr dan Mekanika Gelombang karena salah mengkonfigurasi partikel-partikel penyusun atom. Selain itu siswa mengalami miskonsepsi dalam menggambarkan ukuran partikel-partikel atom jika partikel tersebut dibandingkan satu sama lain. Artinya, siswa tidak mampu mere presentasikan atom dalam multi representasi khususnya menggambarkan submikro partikelpartikel tersebut. Miskonsepsi pada penulisan konfigurasi elektron terjadi karena siswa tidak memahami pembentukan ion positif dan negatif.

1) Petunjuk belajar (Petunjuksiswa/guru)

Pada komponen petunjuk belajar disedia kan petunjuk penggunaan modul baik bagi guru maupun bagi siswa. Petunjuk-petunjuk tersebut akan menuntun pengguna untuk mempelajari materi yang terdapat dalam modul dengan menggunakan model ED3U dan disajikan meng gunakan multi representasi kimia.

2) Kompetensi yang akan dicapai

Pada Modul di tampilkan Kompetensi Inti dan Kompetensi Dasar menyangkut materi struktur atom. Kompetensi Dasar 3 (penge tahuan) dan 4 (keterampilan) di turunkan menjadi 3 indikator pembelajaran dan 16 tujuan pembelajaran yang diperoleh dari analisis tugas pada tahap pendefenisian.

3) Content atau isi materi, Informasi pendukung, Petunjuk kerja berupa Lembar Kerja (LK) dan Latihan disusun berdasarkan model ED3U yaitu eksplorasi, diagnosa, desain, diskusi dan aplikasi. Pada tahap eksplorasi disajikan informasi pendukung yang didalamnya ditampilkan masalah atau kejadian-kejadian tertentu. Berdasarkan informasi tersebut, siswa dituntun dengan pertanyaan-pertanyaan se hingga mengarahkan siswa membuat hipotesis terhadap permasalahan dan kejadian yang di tampilkan. Kegiatan ini ditampilkan pada tahap diagnosis. Pada tahap desain, siswa diminta menuliskan hipotesis mereka berdasarkan jawaban-jawaban pada tahap desain. Konfirmasi terhadap hipotesis mereka disajikan pada tahap diskusi berupa penjelasan dan tuntunan untuk membuktikan hipotesis yang dibuat siswa. Benar tidaknya hipotesis akan terlihat dari jawaban siswa yang disajikan dalam bentuk kesimpulan pada tahap penggunaan. Selain itu, pada tahap penggunaan siswa mengaplikasikan kesimpulan mereka untuk menjawab soal-soal yang diberikan.

4) Evaluasi

Evaluasi disusun berdasarkan indikator dan tujuan pembelajaran yang terdiri dari 30 soal pilihan ganda. Evaluasi disajikan pada akhir modul untuk menguji pemahaman siswa terhadap pembelajaran yang dilakukan.

5) Balikan terhadap hasilevaluasi

Balikan evaluasi adalah berupa kunci jawaban pertanyaan sehingga siswa mengetahui bahwa mereka paham atau tidak dengan materi yang telah disajikan dalam modul. Jika siswa tidak berhasil menyelesaikan evaluasi dengan baik, siswa bisa kembali mempelajari materi pada lembar kegiatan sebelumnya. Hal ini bisa dilakukan berulang- ulang dan sesuai kecepatan siswa.

2. Tahapan pengembangan (develop)

a. Uji Validitas

Uji validitas dilakukan dengan memberikan draft modul yang telah disusun kepada tiga orang dosen pendidikan kimia untuk validasi isi untuk melihat kelayakan modul tersebut dari segi materi dan penyajian. Validasi kegrafikaan dilakukan oleh dua orang dosen Desain Komunikasi Visual untuk melihat kelayakan modul tersebut dari segi desain, tata letak, ukuran huruf dan lain-lain yang termasuk pada tampilan modul.

Berdasarkan hasil uji validitas isi diperoleh hasil yang ditampilkan pada tabel 2 .

Tabel 2. Momen Kappa Komponen Validitas

\begin{tabular}{|c|l|c|l|}
\hline & $\begin{array}{l}\text { Komponen } \\
\text { Validitas }\end{array}$ & Nilai k & Kategori \\
\hline 1 & Kelayakan isi & 0,799 & Tinggi \\
\hline 2 & $\begin{array}{l}\text { Kelayakan } \\
\text { Penyajian }\end{array}$ & 0,889 & $\begin{array}{l}\text { Sangat } \\
\text { tinggi }\end{array}$ \\
\hline 3 & $\begin{array}{l}\text { Kelayakan } \\
\text { Kebahasaan }\end{array}$ & 0,799 & Tinggi \\
\hline & $\begin{array}{l}\text { Kelayakan Modul } \\
\text { secara Keseluruhan }\end{array}$ & 0,829 & $\begin{array}{l}\text { Sangat } \\
\text { tinggi }\end{array}$ \\
\hline
\end{tabular}

Berdasarkan tabel 1. Interpretasi kategori kevalidan berdasarkan nilai momen kappa $(\mathrm{k})$ menurut Bouslaugh (2000) dan tabel 2 diketahui bahwa modul yang disusun secara keseluruhan memiliki validitas sangat tinggi dengan nilai momen kappa 0,829. Secara rinci diketahui bahwa berdasarkan kelayakan isi, modul ini memiliki nilai momen kappa 0,799 yang dikategorikan memiliki validitas tinggi, kelayakan komponen penyajian dengan nilai momen kappa 0,889 yang dikategorikan sangat tinggi dan kelayakan komponen bahasa dengan nilai momen kappa 0,799 yang dikategorikan tinggi.

Validasi isi memberikan beberapa 
perubahan pada modul yang disusun. Perubahan-perubahan tersebut adalah sebagai berikut:

1) Penggantian beberapa gambar, antara lain adalah

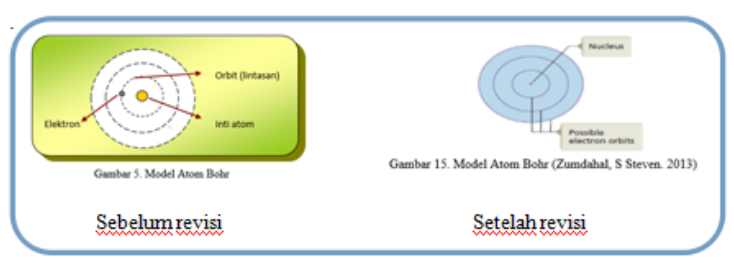

Gambar 2. Revisi Model Atom Bohr Revisi ini dilakukan berdasarkan saran dari validator yaitu inti atom sangat kecil sehingga perlu diperbaiki penggambarannya

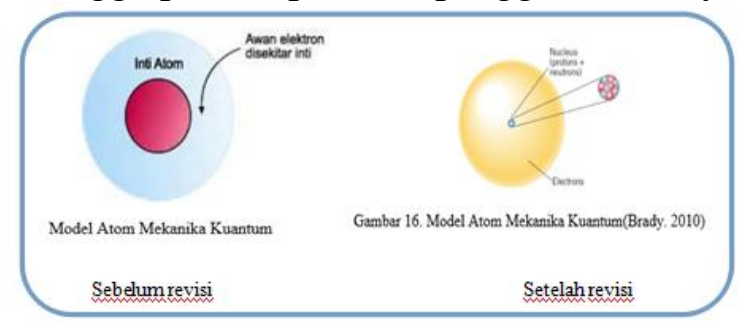

Gambar 3. Revisi Model Atom Mekanika Kuantum

Revisi dilakukan pada ukuran inti atom dimana inti atom sangat kecil, selain itu proton dan neutron penyusun inti atom digambarkan dengan membuat efek zooming pada gambar inti yang kecil.

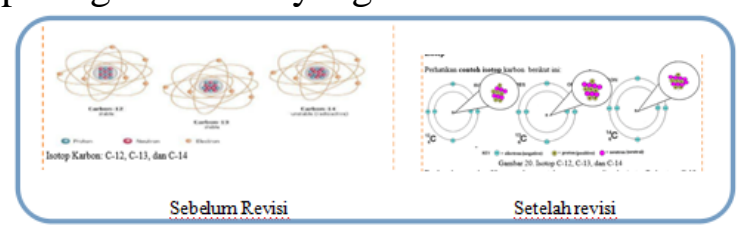

Gambar 4. Revisi Gambar Proton dan

Neutron

Revisi dilakukan pada gambar orbit dan inti atom. Validator menyarankan untuk membuat inti atom sangat kecil dan di buat efek zooming untuk memperlihatkan jumlah proton dan neutron

2) Penambahan sumber gambar

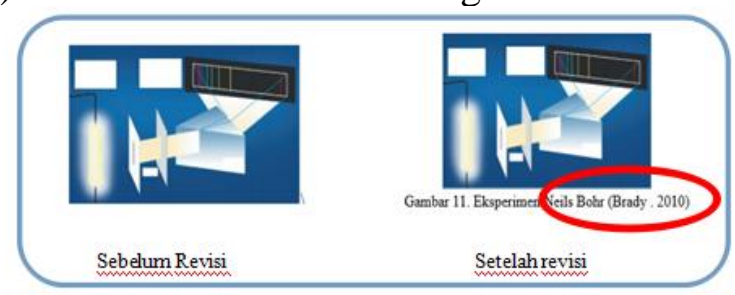

Gambar 5. Revisi Penambahan Sumber Gambar Eksperimen Bohr

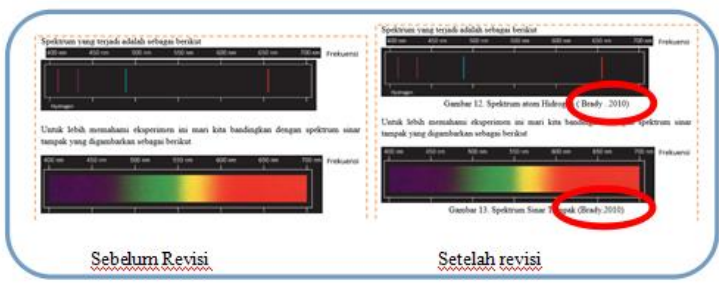

Gambar 6. Revisi Penambahan Sumber Gambar Spektrum

3) Perbaikan penulisan

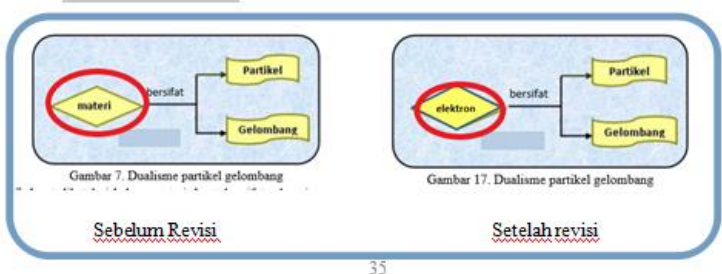

Gambar 7. Revisi Perbaikan Penulisan Materi Menjadi Elektron

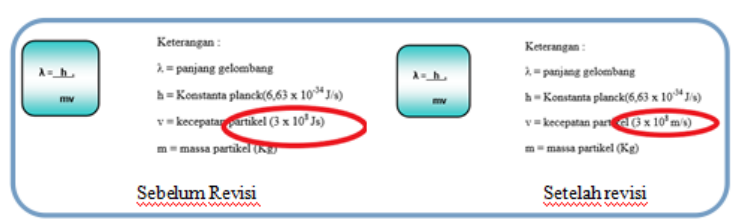

Gambar 8. Revisi Perbaikan Satuan

4) Perbaikan peta konsep

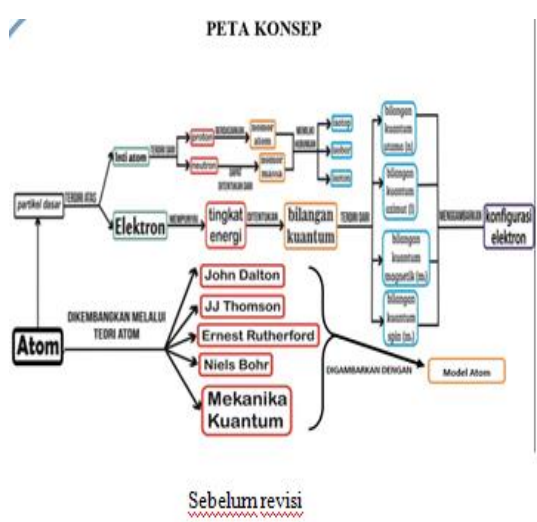




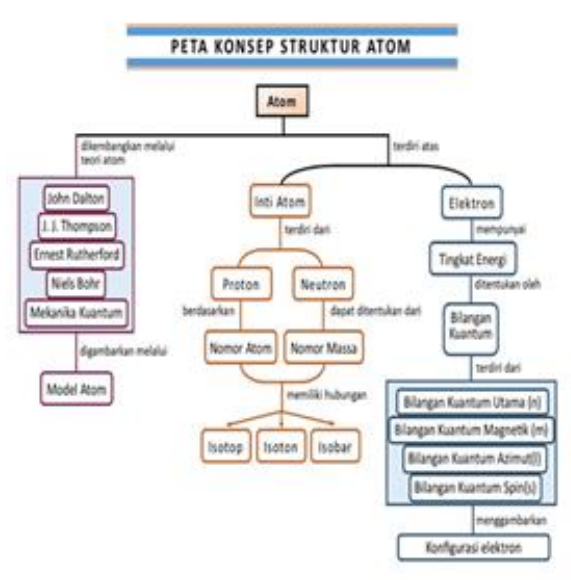

Setelah revisi

Gambar 9. Revisi Peta Konsep

Revisi dilakukan berdasarkan saran dari validator bahwa peta konsep adalah hirarki sehingga dibuat dari atas ke bawah seperti pada gambar setelah revisi, bukan kiri ke kanan seperti gambar sebelum revisi. 5) Penambahan profil dan email penulis

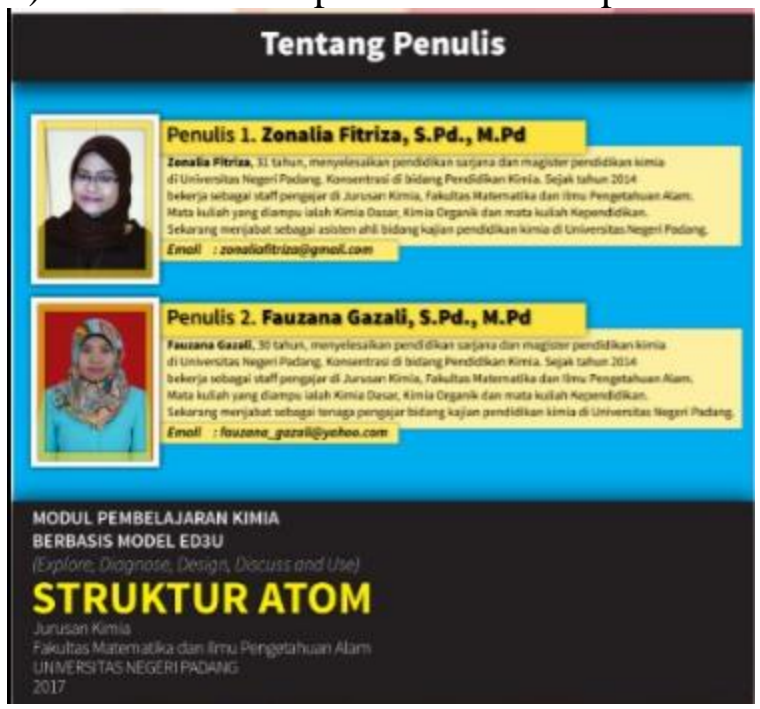

Gambar 10. Penambahan Profil dan Email Penulis

Selain validiasi isi juga dilakukan validasi kegrafikaan oleh dua orang dosen desain komunikasi visual. Hasil validasi kegrafikaan diketahui bahwa secara grafis modul yang dibuat telah valid dengan kategoti tinggi yaitu dengan momen kappa 0,69 . Saran dari validator adalah perbaikan pada cover yaitu dengan menambahkan margin kiri cover.

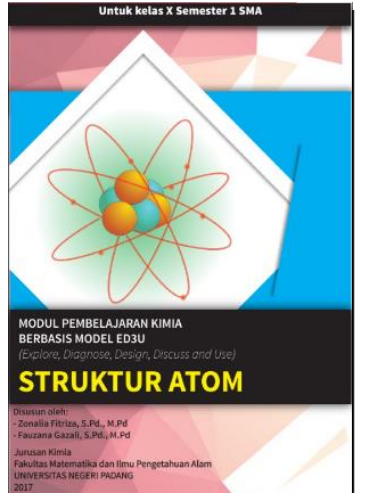

Sebelum revisi

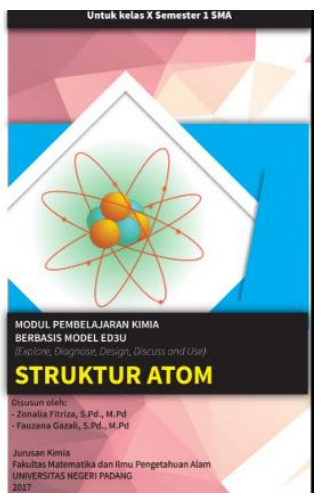

Setelah revisi
Gambar 11. Perbaikan Cover

\section{KESIMPULAN}

Berdasarkan hasil yang diperoleh pada tahap pendefenisian, tahap perancangan dan pengembangan disimpulkan bahwa dihasil kan modul pembelajaran kimia berbasis perubahan konseptual ED3U (Explore, Diagnose, Design, Discuss, Use) Ter integrasi Multi Representasi Pada Materi Struktur Atom yang valid

\section{DAFTAR PUSTAKA}

Boslaugh, Sarah dan Paul A. W. 2008. Statistics in a Nutshell, a desktop quick reference. O'reilly: Beijing, Cambridge, Famham, Köln, Sebastopol, Taipei, Tokyo

Brady, James E. 2009. Chemistry Mattes and Its Change 5th Editon. John Wiley And Sons: NewYork

Depdiknas. 2008. Panduan Pengembangan Bahan Ajar. Direktorat Jenderal Mana jemen Pendidikan Dasar dan Menengah, Direktorat Pembinaan Sekolah Menengah Atas: Jakarta

Dj, Latisma. 2010. Evaluasi Pendidikan. UNP Press : Padang

Fitriza, Zonalia. 2015. Analysis Of Students Misconception of Atomic Structure In SMA Adabiah Padang. International Conference Mathematics, Science, Education and Technology. page 211-216 ISBN978-602-19877-3-5

Kemdikbud. 2013. Salinan Lampiran I Peraturan Menteri Pendidikan dan Kebudayaan RI Nomor 65 tahun 2013 
------------, 2013. Salinan Lampiran I Peraturan Menteri Pendidikan dan Kebudayaan RI Nomor 81A tahun 2013

---------, 2014. Salinan Lampiran I Peraturan Menteri Pendidikan dan Kebudayaan RI Nomor 59 tahun 2014

Kutluay, Yasin. 2005. Diagnosis Of Eleventh Grade Students's Misconceptions About Geometric Optic By A Three-Tier Test. Thesis. Turki : The Graduate School Of Natural and Applied Sciences of MiddleEastTechnical University

Lee, C.K. 2014. A Conceptual Model for Teaching Heat Energy, Heat Transfer and Insulation. Science International Vol 25 (4) :417-437

Park, Eun Jung and Friends. 2009. Understanding Learning Progression in Student Conceptualization of Atomic Structure by Variation Theory forLearning. Lowa City: Paper Presented at the Learning Progression in Science (LeaPS) conference

Reid N. 2009. Working Memory and Science Education: Concusions and Implication, Research in Science \& Technological Education Vol. 27 ( 2) : 245-250
Shope, E Richard, William F McComas. 2015. Modeling Scientific Inquiry to Guide Students in Practices of Science: The ED3U Teaching Model of Conceptual Change in Action. Inquiry Based Learning for Science, Technology, Engineering and Math (STEM) Program, A Conceptual and Practical Resource for Educators Innovation volume4: 217-240

Silberberg, M.S. 2010. Principles of General Chemistry, 2nd ed, The McGraw-Hill Companies Inc: New York

Sugiyono. 2009. Metode Penelitian Bisnis: Pendekatan Kuantitatif, Kualitatif, dan R\&D. Alfabeta: Bandung

Sunyono. 2015. Supporting Students in Learning with Multiple Representation to Improve Student Mental Models on Atomic Structure Concept. Science Education International Vol 26 (2):104-125

Talanquer, V. 2011. Macro, Submicro, and Symbolic: The many faces of the chemistry "triplet", International Journal of Science Education, Vol. 33 (2) :179-195

Trianto. 2010. Mendesain Model Pembelajaran Inovatif Progresif. Kencana: Jakarta 